\title{
Stop and Search Powers in UK Terrorism Investigations: A Limited Judicial Oversight?
}

\section{Genevieve Lennon}

\begin{abstract}
At the pre-trial stage of counter-terrorist investigations, an 'Anglo-Saxon' indulgence towards street-level policing powers has been brought to task by European human rights norms, especially privacy, which are exerting new forms of control over policing discretion and opening judicial oversight over traditional policing activity. This article examines these trends in relation to suspicionless counter-terrorist stop and search. While the European Court of Human Rights applied robust scrutiny in the case of Gillan v United Kingdom, in stark contrast to approach by the House of Lords, there exists a number of challenges which are threatening to weaken judicial scrutiny in this area. First, more recent European Court of Human Rights cases show a more indulgent stance being taken towards policing powers. Second, the precautionary nature of suspicionless counter-terrorist stop and search raises a number of difficulties in relation to effective oversight. In addition, it is a counter-terrorist measure of general application which have, to date, not been subjected to particularly rigorous scrutiny.
\end{abstract}

KEYWORDS: counter-terrorism; policing powers; precaution; stop and search; human rights

(Received 9 December 2014; accepted 20 February 2015)

\section{Introduction}

Street policing powers are notoriously difficult to control: the actions take place away from the oversight of supervisors where the 'norms and practices of the street level police officer take priority over outside regulation'. ${ }^{1}$ It is trite among criminologists that police cultures can be resistant to legal rules which some argue are simply ignored or act solely as a means of framing officer's (prior) conduct. ${ }^{2}$ While accepting that legal rules do not necessarily simply translate into 'blue letter' law and that it can be difficult to exert control, ${ }^{3}$ particularly through legal rules, over street policing, the issue to be addressed here is the 
reluctance of the courts to impose robust oversight in relation to street policing and how this trend, notable in the UK, has been challenged in recent years by the European Court of Human Rights ('ECtHR'), particularly in relation to the right to a private life under the European Convention of Human Rights ('ECHR'), Article 8. This article will describe the tensions between the UK and ECtHR approaches, focusing on the power of suspicionless counter-terrorist stop and search under the Terrorism Act 2000, section 44. The case of Gillan $v$ Commissioner of Police for the Metropolis reveals clear limitations in the UK judiciary's oversight in this area. ${ }^{4}$ The ECtHR applied a far more robust analysis, allowing the appeal in Gillan $v U K .{ }^{5}$ One should, however, be careful in declaring this area now subject to significant judicial control for three reasons. First, subsequent ECtHR cases suggest a more indulgent stance being taken by the court in relation to street policing. Second, the courts, alongside policy makers and academics, have shown some reluctance to insist upon sufficient oversight in relation to protective security measures of general application. Third, the nature of suspicionless counter-terrorist stop and search as a precautionary measure raises a number of challenges for effective oversight. The overall prospects for rigorous judicial oversight therefore appear less promising than at first blush.

The first section below contrasts the weak judicial oversight shown by the House of Lords with the considerably more intensive scrutiny of the ECtHR. The second section discusses the continuing challenges in this area, suggesting that robust judicial oversight may be waning.

\section{The Gillan judgments}

Gillan concerned two claimants who had been stopped under the Terrorism Act 2000, section 44, in London near a protest that was being held outside an arms fair in the ExCel Centre. One was a journalist who was covering the protest; the other was a student who was going to attend the protest. The appellants raised a number of claims: first that under the principle of legality the authorisation should be limited by necessity rather than 'expediency'. Second, they argued that the authorisation and confirmation were ultra vires on the grounds of its geographical and temporal coverage. Third, they argued that the powers infringed their ECHR rights to liberty, under Article 5, to a private life, under Article 8, and to freedom of speech and assembly under Articles 10 and 11. Their claims were rejected on all grounds. 
The principle of legality, as outlined in $R v$ Secretary of State for the Home Department, ex parte Simms, states that when a statutory measure may infringe a human right the judiciary shall, in the absence of express language or necessary implication, interpret the power narrowly so as to avoid or minimise the infringement. ${ }^{6}$ The claimants drew on the Divisional Court's depiction of section 44 as 'sweeping and far beyond anything ever permitted by common law powers' to argue that the power should be exercised only when necessary. ${ }^{7}$ Lord Bingham, giving the leading judgment, dismissed this curtly by noting that "“expedient" has a meaning quite distinct from "necessary"" ${ }^{8}$ In the absence of ambiguity, the principle of legality did not apply.

The second claim related to the practice of the Metropolitan Police Service, which had a rolling, force-wide authorisation in place from February 2001 until July 2009. ${ }^{9}$ This 'extraordinary' ${ }^{10}$ power, nominally limited to a twenty-eight day authorisation, ${ }^{11}$ was thus in force constantly for over eight years across an area of 620 square miles. ${ }^{12}$ The claimants argued the power was not needed across the whole Metropolitan police force area. A senior police officer and civil servant, speaking on behalf of the Secretary of State, gave statements that the threat was dispersed across the entire area and that it was impracticable to try and differentiate between different areas within the force area. The claimants had declined to examine, under special procedures, the closed intelligence supporting the authorisations and provided no evidence to contradict the statements given. It is therefore unsurprising that the House of Lords rejected this ground. Even if there had been evidence which raised doubts, rather than clearly contradicting, the statements given, it seems likely that the court would have shown deference given the nexus of national security, previously described by Lord Diplock as being 'par excellence a non-justiciable question'. ${ }^{13}$

The weak scrutiny applied to the issue of the rolling authorisation is more surprising. While repeated authorisations during extended periods between 2001 and 2008 would have been both conceivable and, arguably, acceptable on the basis of the threat - for example after the July 7, 2005 bombings in London, it is simply untenable that the entire Metropolitan area needed to be subjected to this power for over eight years. The constant usage for seven months prior to $9 / 11$ suggests either extraordinary prescience or the misuse of the power. While, again, the witness statements argued the continuous authorisations were necessary and there was no contradictory expert evidence, this could - and should - have been approached as an issue of statutory interpretation rather than policy. If Parliament had intended to provide 
a permanent power to the police it could have done so. Instead the power was circumscribed by a twenty-eight day limit, underlining its extraordinary nature. Repeated authorisations may have been necessary at times of heightened risk, but continuous authorisations over eight years, amounting nearly to a state of permanence, did not accord with the intention of Parliament.

Only the claims relating to human rights were discussed by subsequently the ECtHR in Gillan $v U K .{ }^{14}$ The following will mirror the approach of the ECtHR, giving a brief overview of Article 5, 10 and 11, while focusing on Article 8 and whether the power was prescribed by law.

The key issue in relation to the right to liberty under Article 5 was whether the action passed the threshold test from a restriction of movement, ${ }^{15}$ to a deprivation of liberty. The instructions relating to the threshold test are relatively clear: one must start with the claimant's actual situation and take into account 'criteria such as the type, duration, effects and manner of implementation of the measure in question. ${ }^{16}$ The practice, however, is a morass. For example, ten hours curfew a day is not a deprivation of liberty, ${ }^{17}$ nor is house arrest for twelve hours each weekday and all weekend. ${ }^{18}$ By contrast, restricting someone for a matter of minutes while forcibly taking a blood sample is a deprivation of liberty. ${ }^{19}$ While the ECtHR implied that Article 5 would apply in the context of section 44, it seems unlikely in light of the later case of Austin $v U K$, discussed below, that an ordinary stop and search would now be deemed to have crossed the threshold. ${ }^{20}$ Nonetheless, the House of Lords' treatment of the issue may be criticised on two grounds. First, it focused on the length of the deprivation, which is not determinative and was disputed on the facts. ${ }^{21}$ Second, while noting the concrete situation in terms of the fact that the persons stopped would 'not be arrested, handcuffed, confined or removed to another place', the court failed to discuss the fact that failure to submit to a search was a criminal offence punishable by up to six month imprisonment and/or a fine. ${ }^{22}$ This was the key issue for the ECtHR, which, while declining to rule on the issue, stated that such coercion 'is indicative of a deprivation of liberty within the meaning of Article 5(1)'. ${ }^{23}$

Rather surprisingly, the House of Lords failed to consider in any depth the application of Articles 10 or 11 to the particular situation of the claimants who were, respectively, attending and reporting on a peaceful protest. Lord Bingham simply stated that it would be 
'hard to conceive of circumstances' in which the power would infringe either right if exercised in accordance with the statute and Code $\mathrm{A}^{\prime} \cdot{ }^{24}$ If it did, he continued, it would be justifiable under the second paragraph of the relevant Article. ${ }^{25}$ 'Code A' is a statutory code of practice governing the exercise of statutory stop and search powers by police officers. ${ }^{26}$ Breach of the Code constitutes neither a civil nor criminal offence but may be considered in questions about the admissibility of evidence. ${ }^{27}$ Section 44 and Code A were so broad that Lord Bingham's assertion is itself questionable, but even leaving that aside, it is very strange that the court felt no need to discuss the particular facts of the claimants. The student had been on his way to protest and turned back following the stop and search. This appears to be a quintessential example of the chilling effect. The journalist, who was accredited and had a press badge, was prevented from covering the protest for between five and thirty minutes. Again, there appears at the very least an arguable case that her right to free speech and assembly were infringed. Certainly, the facts surely merited more than nine and a half lines of discussion.

The ECtHR did not consider Article 10 or 11, given their conclusions in relation to Article 8 , although they did note the risk that such a widely framed power could be misused against demonstrators and protestors. ${ }^{28}$ Declining to discuss rights that apply in only certain circumstances having concluded that the routine exercise of section 44 would unjustifiably infringe the right to a private life is more defensible than the approach taken by the House of Lords. Nevertheless, it is disappointing as attention to expressive rights would have provided useful dicta on the interaction between national security policing powers and those rights, which come into conflict with far more frequency than the issues coming before the courts.

Turning to Article 8, the House of Lords doubted whether a routine exercise of section 44 would engage the right to a private life but did concede that searching personal items, such as a diary, would do so. Lord Bingham drew comparisons with airport searches to which 'passengers uncomplainingly submit'. ${ }^{29}$ This comparison is erroneous. As Lord Bingham stated at the start of his judgment:

It is an old and cherished tradition of our country that everyone should be free to go about their business in the streets of the land, confident that they will not be stopped and searched by the police unless reasonably suspected of having committed a 
criminal offence. So jealously has this tradition been guarded that it has almost become a constitutional principle. ${ }^{30}$

There is a distinction between police powers which are exercised on the 'streets of the land' and at borders. While some airport travel is, of course, internal, the vast majority in the UK some $80 \%$ between 2003 and 2013 - of flights are international. ${ }^{31}$ Therefore, the issue falls to be considered within the norms of border practices which have always been subject to distinct and more onerous conditions of passage than travel within a country. Moreover, as argued by the ECtHR, which was 'unpersuaded by the analogy', travellers at airports give some degree of 'consent' to being subject to heightened security, including being searched, by choosing to travel by air. ${ }^{32}$ There is no comparable choice for people going about their daily business on the streets of London. The search is therefore 'qualitatively different'. ${ }^{33}$ Absent consent, the norm is that the police cannot interfere with a person unless they reasonably suspect the person has, is or is about to commit an offence.

The ECtHR also disagreed with the House of Lords' conclusions regarding routine searches. Again, the coercive nature of the power was central to the court's reasoning that any section 44 search would constitute 'a clear interference with the right to respect for private life' ${ }^{34}$ Drawing attention to the public nature of the search, it noted that this could 'compound the seriousness of the interference because of an element of humiliation and embarrassment'. 35

For an infringement to the rights under Article 5, 8, 10 and 11 to be justified the power must be prescribed by law. This principle has three core components. First, the power must have a basis in law, which includes non-codified law. ${ }^{36}$ Second, the exercise of the power must be foreseeable so as to allow individuals to regulate their conduct. ${ }^{37}$ Third, the measure must be sufficiently bounded to guard against the abuse of power. ${ }^{38}$ It was accepted by both courts that the first limb was satisfied, the power having a basis in the 2000 Act and in Code $\mathrm{A} .{ }^{39}$ The others proved more problematic.

In terms of the authorisation, the nominal safeguards were that the authorisation could only be given by an Assistant Chief Constable or higher ranked officer if 'expedient' for the prevention of terrorism, was limited geographically and temporally, and had to be subject to confirmation by the Secretary of State for the Home Department. ${ }^{40}$ The difficulty with these 
is that while on their face they appear to exert control over the authorisation process, the practice - well known by the time of the case - clearly revealed their inadequacy. While the House of Lords appeared content to rely on the statements given by the police and government witnesses, the ECtHR referred to the actual practice of the police in determining that the safeguards were inadequate. The total failure of the geographical and temporal limits has been discussed. A central issue for the ECtHR was the trigger of 'expediency' which it condemned as being of so low as standard as to preclude any consideration of proportionality. ${ }^{41}$ As regards the confirmation process, the Home Secretary queried 'a few' 42 authorisations and appears ${ }^{43}$ to have refused only one - with a new application approved the following day. ${ }^{44}$ The sense of rubber-stamping was confirmed when it was disclosed in 2010 (after the ECtHR's ruling) that thirty-five authorisations had been confirmed which purported to run over the maximum twenty-eight day period. ${ }^{45}$ While not discussed by the ECtHR, the authorisations were not made public. Initially forces refused to confirm or deny whether they had an authorisation in place and even when this changed, the forces did not take active steps to notify the public an authorisation was in force. ${ }^{46}$ The limitations of these nominal safeguards led the ECtHR to conclude that 'the width of the statutory powers is such that applicants face formidable obstacles in showing that any authorisation and confirmation are ultra vires or an abuse of power'. ${ }^{47}$

In terms of the deployment of the power, Lord Bingham argued that, while no suspicion was required, the power 'cannot, realistically, be interpreted as a warrant to stop and search people who are obviously not terrorist suspects, which would be futile and timewasting, ${ }^{48}$ This raises some questionable presumptions about being able to spot someone who is 'obviously' a terrorist. ${ }^{49}$ It also contradicts the practice whereby, with the notable exception of specific intelligence-led patrols, the power was predominantly used on persons who were under no suspicion of being terrorists, ${ }^{50}$ as borne out by the exceptionally low hitrate. ${ }^{51}$ This is predictable given that the power's primarily objective for the police was deterrence and disruption. ${ }^{52}$ The House of Lords also pointed to Code A as providing an effective curb on the arbitrary deployment of the power, however, as noted by the ECtHR, this only relates to how officers are to proceed once they have stopped someone, it provides no guidance nor restrictions on who should be stopped. ${ }^{53}$

There are therefore only two significant limitations on the deployment of the power. It must be exercised for counter-terrorism purposes and the object of the search must be articles 
of a kind that could be used in connection with terrorism. In relation to the former, the problem is enforcement: it would be exceptionally difficult to prove an officer stopped a person for different reasons, as underlined by Gillan itself. In relation to the latter, as noted by the ECtHR, 'terrorism' is defined so broadly that the object of the search was 'a very wide category which could cover many articles commonly carried by people in the streets' ${ }^{54}$ The ECtHR pointed to the low hit-rate and to the Independent Reviewer of Terrorism Legislation's criticisms in his annual review of terrorism legislation that examples of 'poor and unnecessary use of s.44 abound. ${ }^{55}$ While not raised on the facts, both courts discussed, obiter dicta, the potential for infringement of the prohibition against discrimination, under the ECHR, Article 14, with the ECtHR referring to the statistical evidence of the power's disproportionate use against black and Asian persons. ${ }^{56}$ In relation to the deployment of the power, the ECtHR concluded that 'there is a clear risk of arbitrariness in the grant of such a broad discretion to the police officer'. ${ }^{57}$

Following the refusal of their application to appeal, the UK Government initially raised the authorisation trigger to 'necessary' and limited the use of section 44 to vehicular searches, ${ }^{58}$ before repealing the power and replacing it, initially with an interim power ${ }^{59}$ and then permanently with section $47 \mathrm{~A} .{ }^{60}$ This raised the authorisation trigger to 'necessary', requiring also that the authorising officer 'reasonably suspects' that an act of terrorism will take place. The maximum time limit is now fourteen days and the statute specifically requires that the geographical and temporal limits be 'no more than necessary' to prevent the act of terrorism. ${ }^{61}$ Rolling authorisations are nominally prohibited although the new Code of Practice envisages successive authorisation applications. ${ }^{62}$ The object of the search is slightly narrowed to evidence that the person is a terrorist or the vehicle is being use for terrorist purposes. ${ }^{63}$ While there are some important improvements here, notably in relation to the trigger, the discretions bestowed on authorising officers and those exercising the power remain exceptionally broad. Whether the replacement version sufficiently addresses the ECtHR's concerns remains open to debate as the power has never been used in Great Britain, ${ }^{64}$ despite events such as the Olympics and Royal Wedding in 2012, although it has been used once in Northern Ireland. ${ }^{65}$ 


\section{Challenges to intensive judicial oversight}

The robust decision of the ECtHR in Gillan appeared to settle the issue of how intensive judicial oversight of counter-terrorist street policing powers should be. ${ }^{66}$ However, a three-pronged challenge is now prompting a shift back towards weaker judicial oversight. These are: recent caselaw from the ECtHR which evidences a less robust scrutiny over policing powers; the precautionary nature of section 44; and, the greater reluctance to exert intensive oversight in relation to counter-terrorist powers of general application than those of individual application.

\section{Austin and Colon: towards a weaker oversight?}

Following Gillan, two cases concerning suspicionless stop and search came before the court in the space of just over two years: Colon v Netherlands ${ }^{67}$ and Austin v UK. Colon concerned non-counter-terrorist 'preventive searches' deployed in various Dutch cities, with searches in Amsterdam being at issue in the case. Unlike in Gillan, the ECtHR upheld the preventive searches as justifiably infringing the right to a private life under Article 8 . The relevant issue here is whether this was merited on the basis of the differences between the powers or does it indicate movement on the part of the ECtHR away from an intensive judicial oversight of street policing?

In terms of structure, preventive searches follow the same model as section 44 of prior authorisation followed by deployment of suspicionless stop and search. The Local Council of Amsterdam passed a bylaw under the Municipalities Act, section 151b, which empowered the Burgomaster (Mayor) of Amsterdam, after consultation with the regional head of police and the public prosecutor, to designate areas within the city as 'security risk areas' 'in the event of a public order disturbance caused by the presence of weapons, or if there is a serious fear of such a disturbance occurring. ${ }^{68}$ Thereafter the public prosecutor can empower the police to conduct suspicionless stops and searches of any persons within the security risk areas for selected twelve hour periods.

There are four core differences between the authorisation of preventive searches and of those under section 44. First, the trigger for preventive searches is higher than the equivalent trigger for section 44. However, in practice prior violent weapons incidents were sufficient to trigger designation of an area. Second, the temporal limits are different. The security risk areas were initially designated for six months in November 2002, with repeated 
twelve month designations up to the time of the case in $2009 .{ }^{69}$ While the individual authorisations are considerably longer than section 44 authorisations were, the end result of rolling authorisations is common to both. The Dutch innovation is the added requirement that the public prosecutor thereafter empowers the police for twelve hour periods. Third, the process is led by the Burgomaster in the Netherlands, albeit in consultation with the police and public prosecutor, whereas section 44 was police led, with confirmation by the Home Secretary. The ECtHR emphasised the value of the safeguard of democratic control over preventive searches. In this aspect they may have been pointing to the Burgomaster's central role and also to the facts that the Local Council had passed the bylaw permitting the designation of security risk areas and that it could be repealed or amended with more ease than primary legislation. ${ }^{70}$ Fourth, the designation of a security risk area was made public.

While there is more democratic involvement, by way of the Burgomaster, the authorisation process for preventive searches remains highly discretionary. The role of the public prosecutor may act as an effective curb on arbitrary authorisations; however, on paper the role of the Secretary of State could have done the same. The question is the practice, which, in contrast to their approach in Gillan, the ECtHR did not discuss.

In terms of deployment, the discretion afforded to Dutch officers was narrower in that the object was offensive weapons, which is considerably more circumscribed than 'articles that could be used in connection with terrorism.' However, these remain suspicionless stops and searches, with the accompanying exceptionally broad discretion and were coercive: failure to submit to a search constituted a criminal offence punishable by a fine or up to three months' imprisonment. ${ }^{71}$ Remarkably, the ECtHR's response was to note that the police were briefed and debriefed - as the officers deploying section 44 were - and that 'they were given no latitude in deciding when to exercise their powers, which ruled out any risk of arbitrariness. ${ }^{72}$ This is nonsense. The discretion of concern here is that of the officer in choosing whom to stop; whether it is within one hour, twelve hours or twenty days, the discretion remains the same.

An important differential for the ECtHR was that the Dutch Government was able to rely upon two independent studies that attested to the effectiveness of the powers, recommending their continued use. Effectiveness is important, but it is only relevant in relation to the justification of an infringement under Article 8(2); it does not speak to whether 
the measure is prescribed by law. It is disappointing that the ECtHR did not discuss the statistics on the usage of the preventive search powers in detail. Between 2003 and 2006 across Amsterdam and Rotterdam there were 143,606 preventive searches carried out. ${ }^{73}$ This compares with 125,895 section 44 stops between 2002/03 and 2006/07 by all Home Office forces in England and Wales. ${ }^{74}$ There was no discussion in Colon of the potential for preventive searches to be disproportionately used against ethnic minorities, nor was the issue discussed in detail in the reports attesting to the power's effectiveness. There is little research on the matter, but the EU Minorities and Discrimination Survey has shown that, at least some, ethnic minorities in the Netherlands believe they are being targeted for stop and search by the police because of their ethnicity. ${ }^{75}$

So, while there are differences between preventive searches and section 44 , these are not as profound as the ECtHR's judgment suggests. What is most worrying about Colon is the lack of intensive scrutiny by the ECtHR. The various mechanisms in Colon provide slightly more oversight than those for section 44 , but - and this is the crucial point - the issue is whether they are used and effective. Just as the Home Secretary's role could have provided significant scrutiny but in fact merely rubberstamped the authorisations, so too the various controls in Colon may be non-existent in practice. Instead of inquiring into the practice, as it had done in Gillan, the ECtHR simply pointed to the structures and presumed their adequacy. This lax approach of the ECtHR in Colon has been followed in the UK in a case which distinguished Gillan. ${ }^{76}$

Another street policing case, Austin v UK, was heard by the ECtHR three months prior to Colon. The case was not about counter-terrorism powers and was about 'kettling' (the police tactic for controlling crowds by the containment within a limited area of a crowd gathered to demonstrate in a public place by the formation of a large perimenter cordon of police officers) rather than suspicionless stop and search, but the approach of the Court lends further weight to the impression that Gillan may have been the high point of intensive judicial scrutiny by the ECtHR over street policing powers.

The case concerned the kettling by the Metropolitan Police Service of a crowd of between 2,000 and 3,000 people during the May Day protests in London in 2001. ${ }^{77}$ The claimants alleged they had been deprived of their right to liberty under Article 5, ECHR. The majority of the crowd - some $60 \%$ - were not suspected of committing, having committed or 
being about to commit any offence. ${ }^{78}$ This creates difficulties in fitting the police action under any of the exceptions provided in the sub-paragraphs of Article 5(1). Rather than attempt what would have been, at best, a strained interpretation of Article 5(1)(b) or (c), ${ }^{79}$ the Grand Chamber of the ECtHR determined that Article 5 did not apply due to the 'specific context and circumstances' of the restriction. ${ }^{80}$

The Court reasoned that 'situations commonly occur in modern society where the public may be called on to endure restrictions on freedom of movement or liberty in the interests of the common good', ${ }^{81}$ citing the examples of travel by public transport or attending a football match. It concluded that

such commonly occurring restrictions on movement, so long as they are rendered unavoidable as a result of circumstances beyond the control of the authorities and are necessary to avert a real risk of serious injury or damage, and are kept to the minimum required for that purpose, can[not] properly be described as "deprivations of liberty" within the meaning of art.5(1). ${ }^{82}$

The claimants in the case had been held in Oxford Circus in central London for seven and half hours without access to toilet facilities, food, water or shelter. ${ }^{83}$ This is not analogous to waiting to exit a football stadium nor to being stuck in one's car on a motorway. The former is subject to consent, the latter is arguably not a deprivation of liberty, it is choice between abandoning one's property or not (again - a choice). ${ }^{84}$ As noted in the dissenting opinion of Judges Tulkens, Spielmann and Garlicki, the intention of the measure has no place in determining whether there has been a deprivation of liberty or not; it is relevant only to the application of the sub-paragraphs of Article 5(1). The expansion by the ECtHR of the requirement to consider the "type" and "manner of implementation" 85 in Guzzardi v Italy to include 'purpose' has no precedence. ${ }^{86}$ What is more, there was no need to create this ambiguous and dangerous precedent; the ECtHR could simply have argued the situation did not cross the threshold test as it was without adding the new criteria of purpose.

Leaving to one side the difficulties with the Austin judgment, the interest here is the intensity of the scrutiny which the court applied to the police action, which was low. The ECtHR strongly emphasised subsidiarity and the difficulties of modern policing, particularly policing crowds able to organise themselves by way of social media. ${ }^{87}$ These are valid points, 
and it is of course correct that the Court relied heavily on the findings of fact by the judge at first instance. ${ }^{88}$ But the difference between the four claimants - three of whom were simply passing through the area and became caught in the cordon - was deemed irrelevant. ${ }^{89}$ Nor was the issue, discussed in the dissenting opinion, that the findings of fact suggest that the decision to kettle was one taken for expediency and that 'the police could have been expected to apply less intrusive means,.$^{90}$ Austin is a far cry from the scrutiny applied by the ECtHR in Gillan.

The ebbing of intensive judicial oversight, if that is what Austin and Colon signify, could be partially prompted by realpolitik on the part of the ECtHR. Certainly Austin, with its emphasis on subsidiarity, appeared to be addressing, at least in part, the trenchant criticism of the Court's jurisprudence among some British politicians, political parties and media. ${ }^{91}$ While this section of the article has shown that the intensity of judicial scrutiny evident in Gillan was not replicated in Colon or Austin, two swallows do not a summer make nor do two cases prove a 'trend'. However, they do suggest that caution should be exercised before hailing the scrutiny applied in Gillan as the norm. Whether Gillan is the high tide of judicial scrutiny is likely to take years to determine.

\section{Oversight of precautionary powers and measures of general application}

Another challenge to effective oversight relates to the precautionary nature of suspicionless counter-terrorist stop and search. Suspicionless counter-terrorist stop and search is emblematic of all-risks policing in which the risk calculation is reversed, shifting from 'persons to actions and objects'. ${ }^{92}$ In placing persons under suspicion in advance of any risky behaviour on their part, powers such as section 44 adopt a precautionary stance. Thus, action is taken before the risk materialises, or even before it is known whether the risk will materialise, on the basis that the consequences of a successful attack would be too grave. As with pre-emptive criminal measures, ${ }^{93}$ precautionary ones raise a variety of problems for the criminal law. ${ }^{94}$ Of these, two are of particular relevance to judicial scrutiny of such powers. First, precautionary measures require vague drafting. As these measures are designed to operate in conditions of uncertainty, it is not possible to draft the power with a high degree of specificity. Just as precautionary offences tend to be defined in 'broad, imprecise terms, ${ }^{95}$ so too precautionary policing powers are broadly drafted. To do otherwise would undermine the entire purpose of precaution, which is to allow action when there is no certainty. Second, for similar reasons, precautionary measures require broad discretion be bestowed upon the 
officer. Precautionary measures are designed to permit action when it is unclear from whom the threat will emerge, if at all. In such circumstances it is impossible to delineate discretion. The prime constraint in all-risks policing measures is their geographical range: the location is deemed to be at risk therefore all persons entering it are presumed to be suspicious until proven otherwise. However, this does little to curb the discretion of an officer regarding who to stop.

Of course, the issue is not the discretion itself but rather the potential for arbitrary treatment which this affords. One way of addressing this, used with analogous US counterterrorist suspicionless stop and search powers in the US,${ }^{96}$ is to apply a pre-determined selection rate, such as stopping every fifth person. While circumventing the potential for the arbitrary exercise of the power, this approach has a number of flaws. It is predictable, potentially allowing would-be terrorists to avoid being searched, although this could be circumvented by cycling different selection rates or by applying random selection criteria. Such an approach prevents officers from deploying the power when there is, for example, a weak indication by a police dog or behavioural analysis that falls short of reasonable suspicion. In domestic law it would constitute the fettering of a discretion with policy which is not permitted under administrative law, ${ }^{97}$ although this could be addressed by the statute explicitly permitting such an approach. More problematic are the statements by both the HL and the ECtHR in Gillan disapproving the practice of stopping persons who are obviously not suspicious. $^{98}$

The most effective way of ensuring deterrence while limiting the potential for arbitrary selection is to subject every person in the area to a search, thereby extinguishing the officers' discretion. This is the approach taken in airports, albeit often with an added layer of enhanced security applied to those deemed suspicious and/or chosen by way of predetermined selection criteria. This approach can only work in limited geographical areas where there is a clear through-flow of persons and people are aware in advance of the security systems and prepare for them by attending the location with time to spare. This approach cannot operate in public areas where persons are unaware in advance that they will be subjected to a search and consequential delays. Nor could such an approach work with mass transit systems such as the London Underground. The core function of such systems is to rapidly transport extremely large numbers of people. While safety is an important concern, applying airport style searches would undermine the prime objective of mass transport 
systems by unduly slowing down the flow of passengers. Moreover, it still does not answer the courts' concern regarding the targeting of persons of whom there is obviously no suspicion. In the airport scenario this is addressed by presuming implied consent is given by travellers. It is questionable whether such reasoning can apply to mass transit systems on which most passengers travel by necessity.

Beyond limiting officers' discretion, the alternative, if such powers are to be used, is to ensure close oversight ex ante of the authorisation and post hoc of both the authorisation and deployment. Much of this would most effectively be done by relevant public bodies, such as the Home Secretary in Gillan - were the role, of course to be more than rubberstamping or the public prosecutor and Local Council in Colon, external reviewers such as the UK's Independent Reviewer of Terrorism Legislation, ${ }^{99}$ parliamentary committees and community bodies. The role of the court would be to ensure, as they did in Gillan, that these bodies actually exert close scrutiny and to demand evidence of such, unlike the unquestioning acceptance of effectiveness that occurred in Colon.

The authorisation of such powers could be subjected to judicial confirmation, whether as an alternative or in addition to oversight by other bodies. This could enable close, independent scrutiny providing a robust method of oversight. In Colon, while the ECtHR rejected the claim that prior judicial control was required to ensure a power is prescribed by law, it acknowledged that it was 'desirable in principle'. ${ }^{100}$ The question therefore becomes whether it is 'feasible in practice'? ${ }^{101}$ The answer is yes and there is precedence for such practice in the UK with the judicial oversight of extensions to pre-charge detention of terrorist suspects under the Terrorism Act 2000, section 41, and in relation to Terrorism Prevention Investigation Measures. ${ }^{102}$

One final concern is that within counter-terrorism, measures of general application, like suspicionless counter-terrorist stop and search under section 44, have arguably suffered from even less scrutiny than individualised powers, whether from policy makers, academics or judges. This occurs in part because of the diffused impact of such measures, in part because some of their costs fall upon the private sector who are willing to bear them, and, in part because the impact of some of the measures is less obvious, as with, for example, mass surveillance. ${ }^{103}$ Police powers of general application have a chequered history in this regard. Suspicionless stop and search under section 44 represents a significant achievement in terms 
of judicial scrutiny which brought about legislative changes that had been resisted up to that point, notwithstanding some significant criticism of the power by parliamentary committees and the Independent Reviewer for Terrorism Legislation as well as communities. ${ }^{104}$ Suspicionless stop and search at borders, under the Terrorism Act 2000, schedule 7 has a more inconsistent track record. The powers have recently been amended and slightly curtailed $^{105}$ but of four domestic judicial challenges, one succeeded on very unusual facts, ${ }^{106}$ one on very narrow grounds, ${ }^{107}$ and two have, to date, failed (including the case of David Miranda in which issues of expressive rights were briefly considered). ${ }^{108}$ Another is on appeal to the ECtHR. ${ }^{109}$

\section{Conclusion}

The intensive scrutiny applied in Gillan by the ECtHR in analysing the legal issues and in particular the actual practice of suspicionless counter-terrorist stop and search under section 44 contrasts sharply with the approach taken by the House of Lords. The ECtHR's judgment stands out further given that it dealt with street policing and counter-terrorism, two areas where intensive judicial oversight has often been lacking. However, subsequent judgments by the ECtHR appear to show a less robust scrutiny being applied.

The precautionary nature of suspicionless counter-terrorist stop and search, and the fact that the powers are counter-terrorist measures of general application, suggest that, even at its zenith, judicial scrutiny may not be sufficient to manage the challenges presented. Such powers necessitate close oversight ex ante and post hoc. This requires analysis not only by the judiciary but also the legislature, including parliamentary committees, independent experts - such as the UK's Independent Reviewer of Terrorism Legislation, and community bodies who can provide a bridge towards legitimacy. ${ }^{110}$ The judges should not shoulder the entire burden and, adapting from Ben Bowling's call in relation policing, perhaps what should be aspired to is 'good enough judicial oversight'. At the very least this requires scrutiny of the actual practices of the police, not simply a bare recital of structures which may or may not function.

\footnotetext{
${ }^{1}$ Andrew Sanders and Richard Young, 'Police powers', in Tim Newburn (ed.), Handbook of Policing (Cullompton: Willan 2003) 229.
} 
${ }^{2}$ See, for example: Simon Holdaway, 'Discovering Structure: Studies of the British Police Occupational
Culture' in Mollie Weatheritt (ed.), Police Research: Some Future Prospects (Aldershot: Avebury 1989). Michael Chatterton 'The Cultural Craft Of Policing - Its Past And Future Relevance', Policing and Society 5 (1995): 97. Richard Ericson, Making Crime: A Study Of Detective Work (Toronto: University of Toronto Press, 1993).

${ }^{3}$ Robert Reiner and Leonard Leigh, 'Police power', in Gerald Chambers and Christopher McCrudden (eds.), Individual rights and the Law in Britain (Oxford: Clarendon Press 1994).

${ }^{4}$ Gillan v Commissioner of Police of the Metropolis [2006] UKHL 12 ('Gillan(HL)')

${ }^{5}$ App. no.4158/05 , (2010) 50 EHRR 45.

${ }^{6} R v$ Secretary of State for the Home Department, ex parte Simms [2000] 2 AC 115, 131 (per Lord Hoffmann).

${ }^{7} R$ (on the application of Gillan) $v$ Commissioner of Police of the Metropolis [2003] EWHC 2545 (Admin)

('Gillan (Divisional)') [44]. See also $R$ (on the application of Gillan) $v$ Commissioner of Police of the Metropolis [2004] EWCA Civ 1067 [8].

${ }^{8} \operatorname{Gillan}(H L)[14]$.

${ }^{9}$ Metropolitan Police Service Section 44 Authorisation Data (London: Metropolitan Police Service 2010). The authorisation had to be limited to the police area, including internal waters, and need not extend that far (Terrorism Act 2000, ss 44(4), (4A), 44(4B) and 44(4ZA) (emphasis added)).

${ }^{10}$ Gillan (Divisional) [44].

${ }^{11}$ Terrorism Act 2000, s.46(2).

${ }^{12}$ Approximately 997 square kilometres. Metropolitan Police Service 'About the Met'

$<\mathrm{http}: / /$ content.met.police.uk/Site/about> (accessed $1^{\text {st }}$ December 2014).

${ }^{13}$ Council of Civil Service Unions v Minister for the Civil Service [1985] 1 AC 374, 412 (Lord Diplock).

${ }^{14}$ Gillan (ECtHR).

${ }^{15}$ Protected under Article 2 of Protocol 4, which the UK has not ratified.

${ }^{16}$ Guzzardi v Italy App. no.7367/76, Ser A 39, (1981) 3 EHRR 333, [92].

${ }^{17}$ Raimondo v Italy App.no.12954/87, Ser A 281-A, (1994) 18 EHRR 237.

${ }^{18}$ Trijonis v Lithuania App.no.23333/02, 17 March 2005.

${ }^{19} X v$ Austria App. no.8278/78, DR 18, 154, 13 December 1979.

${ }^{20}$ App.no.39692/09, (2012) 55 EHRR 14 ('Austin (ECtHR)').

${ }^{21}$ It was agreed the stop of the student lasted around twenty minutes but the journalist claimed her stop had taken around thirty minutes while the police claimed it was closer to five.

${ }^{22}$ Terrorism Act 2000, s.47.

${ }^{23}$ Gillan (ECtHR) [57]. See also Foka v Turkey App.no.28940/95, 24 June 2008.

24 'The Police and Criminal Evidence Act 1984 Code A: Code of Practice for the exercise by: Police Officers of statutory powers of stop and search' (London: Home Office, 2008).

${ }^{25} \operatorname{Gillan}(H L)$ [30].

${ }^{26}$ The relevant version was Code issued under Police and Criminal Evidence Act 1984 (Codes of Practice)

(Revisions to Code A) (No.2) 2008, SI 2008/3146.

${ }^{27}$ Police and Criminal Evidence Act 1984 s 67(10)-(11).

${ }^{28}$ Gillan (ECtHR) [85].

${ }^{29} \operatorname{Gillan}(H L)$ [28].

${ }^{30}$ Ibid., [1].

${ }^{31}$ Department of Transport Air Traffic by Type Of Service, Operator And Airport, UK: Time Series (London:

Department of Transport, 2013).

${ }^{32}$ Gillan (ECtHR) [64].

${ }^{33}$ Ibid., [64].

${ }^{34}$ Ibid., [63].

${ }^{35}$ Ibid., [63].

${ }^{36}$ Sunday Times v United Kingdom App.no.13166/87, Ser A 217, (1992) 14 EHRR 229.

${ }^{37} S$ and Marper $v$ United Kingdom App.no. 30562/04, 4 December 2008, (2009) 48 EHRR 50.

${ }^{38}$ Huvig v France App.no.11105/84, Ser A 176-B, (1990) 12 EHRR 528.

${ }^{39}$ Gillan (HL) [75]; Gillan (ECtHR) [78].

${ }^{40} \mathrm{TACT}$, ss $44,46$.

${ }^{41}$ Gillan (ECtHR) [80].

${ }^{42}$ Genevieve Lennon Policing Terrorist Risk: Stop and Search under the Terrorism Act 2000, Section 44 (unpublished PhD thesis, Leeds: University of Leeds, 2011) quoting Lord Carlile (the Independent Reviewer of Terrorism Legislation).

${ }^{43}$ Full data for all forces has never been released. However, see Lord Carlile Report on the operation in 2009 of the Terrorism Act 2000 and of Part I of the Terrorism Act 2006 (London: HMSO, 2010) para 55 c.f. Gillan v $U K[80]$. 
${ }^{44}$ Metropolitan Police Service Section 44 Authorisation Data (London: Metropolitan Police Service, 2010).

${ }^{45}$ Hansard (House of Commons) vol.511 cols.24WS-28WS 10 June 2010 (Herbert, Nick MP).

${ }^{46}$ Metropolitan Police Service Section 44 Authorisation Data.

${ }^{47} \operatorname{Gillan}(E C t H R)$ [80].

${ }^{48} \operatorname{Gillan}(H L)$ [35].

${ }^{49}$ See, further Marc Sageman, Understanding Terror Networks (Philadephia: University of Pennsylvania Press, 2004).

${ }^{50}$ Lennon Policing Terrorist Risk.

${ }^{51}$ Within the Home Office forces, there were 332 terrorism related arrests from 578,048 stops (Home Office, Statistics on Race and the Criminal Justice System (London: Home Office, 2002-2004, 2006); Ministry of Justice, Statistics on Race and the Criminal Justice System (London: Ministry of Justice, 2007-2011).

${ }^{52}$ Lennon 'Policing Terrorist Risk'.

${ }^{53}$ Gillan (HL) [29], [30], [35] (Lord Bingham); [55] (Lord Hope); Gillan (ECtHR) [83].

${ }^{54} \operatorname{Gillan}(E C t H R)$ [83].

${ }^{55} \operatorname{Gillan}(E C t H R)$ [84].

${ }^{56}$ Gillan (ECtHR) [85]. See also Gillan (HL) [43]-[47] (Lord Hope) and [76]-[92] (Lord Brown).

${ }^{57}$ Gillan (ECtHR) [85].

${ }^{58} \mathrm{HC}$ vol 513 col 5408 July 2010 (Theresa May, MP)

${ }^{59}$ Terrorism Act 2000 (Remedial) Order 2011, SI 2011/631.

${ }^{60}$ Protection of Freedoms Act 2012, s 61.

${ }^{61} \mathrm{TACT}$, section $47 \mathrm{~A}(1)(\mathrm{b})$.

${ }^{62}$ Home Office, Code of Practice for the Exercise of Stop and Search Powers (London: Home Office 2012) para. 4.3.

${ }^{63} \mathrm{TACT}$, section $47 \mathrm{~A}(4)$.

${ }^{64}$ David Anderson, The Terrorism Acts in 2013 (London: Home Office, 2014) paras 6.9-6.11.

${ }^{65}$ See further: Ed Cape, 'The Counter-Terrorism Provisions of the Protection of Freedoms Act 2012: Preventing

Misuse or a Case of Smoke and Mirrors?', Criminal Law Review (2013): 385; John Ip, 'The Reform of Counterterrorism Stop and Search after Gillan v United Kingdom', Human Rights Law Review 13 (2013): 729.

${ }^{66}$ Although note that the lower UK courts must follow the ratio decidendi of the House of Lords in Gillan rather than that of the ECtHR if the case is indistinguishable (Kay v Lambeth London Borough Council [2006] 2 AC 465). Two subsequent cases in which this issue has been raised, one concerning non-counter-terrorist suspicionless stop and search ( $R$ (on the application of Roberts) $v$ Commissioner of Police of the Metropolis [2014] EWCA Civ 69) and the other concerning stop, search and question under the Terrorism Act 2000, schedule 7, have both distinguished Gillan (Beghal v DPP [2013] EWHC 2573 (Admin)).

${ }^{67}$ Colon v Netherlands (2012) 55 EHRR SE5 app.no.49458/06.

${ }^{68}$ Municipalities Act, s. 155 .

${ }^{69} \mathrm{~A}$ twenty-four month designation was issued in June 2005 but reduced to twelve months that October (Colon [15]-[16].

${ }^{70}$ In fact section 44 was amended with relative ease, the Government passing an urgent Remedial Order under the Human Rights Act 1998, s10 (Terrorism Act 2000 (Remedial) Order 2011 SI 2011/631).

${ }^{71}$ Netherlands Criminal Code, Art. 184.

${ }^{72}$ Colon [68].

${ }^{73}$ Joanne van der Leun and Maartje van der Woude, 'Ethnic Profiling in the Netherlands? A Reflection on Expanding Preventive Powers, Ethnic Profiling and a Changing Social and Political Context', Policing \& Society 21 (2011): 444, 449. See also COT Institute for Safety and Crisis Management, Evaluatie Preventief Fouilleren in Amsterdam: opbrengsten,wapenincidenten en hot spots (The Hague: COT, 2007); COT Institute for Safety and Crisis Management, Evaluatie Preventief Fouilleren in Amsterdam: de stand van zaken (The Hague: COT, 2006).

${ }^{74}$ Home Office, Statistics on race and the criminal justice system; Ministry of Justice, Statistics on race and the criminal justice system (see fn51).

${ }^{75}$ See van der Leun and van der Woude, fn.73. 450-451.

${ }^{76} R$ (Roberts).

${ }^{77}$ Austin (ECtHR) [20] cf Austin v Commissioner of Police of the Metropolis [2009] UKHL 5 [3].

${ }^{78}$ Austin (HL) [6].

${ }^{79}$ See further Austin v Commissioner of Police of the Metropolis [2005] EWHC 480; Genevieve Lennon 'Police Powers: Article 5 ECHR and Crowd Control', Web Journal of Current of Current Legal Issues 3 (2009); Genevieve Lennon 'The Purpose of the Right to Liberty under the ECHR, Article 5' Web Journal of Current of Current Legal Issues 3 (2012).

${ }^{80}$ Austin (ECtHR) [59].

${ }^{81} \mathrm{Ibid}$. 
${ }^{82}$ Ibid.

${ }^{83}$ Austin (HL) [6].

${ }^{84}$ David Mead 'Kettling Comes To The Boil Before The Strasbourg Court: It Is A Deprivation Of Liberty To

Contain Protesters En Masse?', Cambridge Law Journal 71 (2012): 472, 473.

${ }^{85}$ Austin (ECtHR) [65].

${ }^{86}$ Guzzardi v Italy, fn.16. See also Engel v Netherlands App.no.5100/71, Ser A 22, (1979-80) 1 EHRR 706.

${ }^{87}$ Austin (ECtHR) [56]; [61].

${ }^{88}$ Austin (ECtHR) [62], [66]-[67].

${ }^{89}$ Austin (ECtHR) [63] c.f. dissenting opinion [11] and $R$ (on the application of Laporte) $v$ Chief Constable of Gloucestershire [2006] UKHL 55.

${ }^{90}$ Austin (ECtHR) Dissenting judgment [10].

${ }^{91}$ Most recently the Conservative Party have pledged to withdraw from the ECHR if they are not permitted to veto the judgments of the ECtHR, see: Conservative Party 'Protecting human rights in the UK' (London: 2014).

${ }^{92}$ Clive Walker 'Know thine enemy as thyself': Discerning friend from foe under anti-terrorism laws',

Melbourne University Law Review 32 (2008): 275, 277.

${ }^{93}$ See further Andrew Ashworth and Lucia Zedner Preventive Justice (Oxford: Oxford University Press, 2014)

and Andrew Ashworth, Lucia Zedner and Patrick Tomlin, eds., Prevention and the limits of the criminal law

(Oxford: Oxford University Press, 2013).

${ }^{94}$ Genevieve Lennon 'Precautionary tales: suspicionless counter-terrorist stop and search' Criminology and

Criminal Justice 15 (20135): 44-early online access.

${ }^{95}$ Lucia Zedner 'Fixing the future? The pre-emptive turn in criminal justice', in Bernadette McSherry, Alan

Norrie and Simon Bronnit (eds.), Regulating Deviance: The Redirection of Criminalisation and the Futures of

Criminal Law (Oxford: Hart 2009) 49.

${ }^{96}$ See further Genevieve Lennon 'Security inspections: suspicionless counter-terrorist stop and search in the

USA and UK' in Genevieve Lennon and Clive Walker (eds.), Routledge Handbook of Law and Terrorism

(London: Routledge, 2015).

${ }^{97}$ British Oxygen Co Ltd v Board of Trade [1971] AC 610.

${ }^{98}$ Gillan (HL) (n 67); Gillan (ECtHR) (n 31).

${ }^{99}$ See Terrorism Act 2006, s.36.

${ }^{100}$ Colon [75].

${ }^{101}$ Colon [75].

102 Terrorism Investigation and Prevention Measures Act 2011.

${ }^{103}$ See further Clive Walker, '"Protect" Against Terrorism: In Service Of The State, The Corporation, Or The

Citizen?' in David Jenkins, Amanda Jacobsen and Anders Henriksen (eds.), The Long Decade: How 9/11

Changed the Law (New York: Oxford University Press, 2014) 199-200 and Amos Guiora, Genevieve Lennon and Clive Walker 'Homeland Security' in Genevieve Lennon and Clive Walker (eds.), fn.96.

${ }^{104}$ See, for example: Lord Carlile Report on the operation in 2009 of the Terrorism Act 2000 and of Part I of the Terrorism Act 2006; The Metropolitan Police Authoristy Review of police use of counter-terrorism Stop and Search powers in London (London: MPA, 2007); Liberty The Impact of Anti-Terrorism Powers on the Britihs Muslim Population (London: Liberty, 2004); Home Affairs Committee Terrorism and Community Relations (2004-05 HC 165-I); Joint Committee on Human Rights Demonstrating Respect for Rights? (2008-09 HL 47I/HC 320-I).

105 Anti-social Behaviour, Crime and Policing Act 2014, s 148 and Schedule 9.

${ }^{106}$ CC v Commissioner of Police of the Metropolis [2011] EWHC 3316 (Admin) (where CC, already the subject of a control order, was detained and questioned so as to obtain information untainted by torture allegations which would confirm the propriety of the control order; held that the power had been used for improper purposes).

${ }^{107}$ Elosta $v$ Commissioner of Police of the Metropolis [2013] EWHC 3397 (Admin) (holding that, having requested a solicitor, the detainee should not have been questioned until the solicitor arrived).

${ }^{108}$ Beghal fn.66; $R$ (on the application of Miranda) $v$ Secretary of State for the Home Department [2014] EWHC 255 (Admin).

${ }^{109}$ See Malik $v$ United Kingdom (admissibility) App.no.32968/11, (2013) 57 EHRR SE13. The case was not subject to judicial review domestically.

${ }^{110}$ See further John Ip 'Terrorism Laws and Constitutional Accountability' in Genevieve Lennon and Clive Walker (eds.), fn.96; Fiona de Londras and Fergal Davis, 'Controlling the Executive in Times of Terrorism: Competing Perspectives on Effective Oversight Mechanisms’, Oxford Journal of Legal Studies 30 (2010): 19.

\section{Notes on Contributor}


Dr Genevieve Lennon is Chancellor's Fellow at the School of Law, University of Strathclyde. She holds a PhD in law from the University of Leeds. Her research interests lie in the areas of counter-terrorism law and policy, in particular in relation to human rights, accountability and counter-terrorist policing. She has published and presented on various aspects of counter-terrorism and policing. She was an invited attendee at Home Office/Homeland Security workshops on 'Greenfield Aviation Security 2027' (2010). She is currently co-authoring a monograph, Protective Security against Terrorism (Cambridge University Press). Dr Lennon holds a BA from the National University of Ireland, Galway, an MA from the University of York and an LLM at the University of Leeds.

Email: genevieve.lennon@strath.ac.uk 